\title{
MULTIPLE, SHIFTING AND CONTESTED: DALIT WRITINGS AND DR. AMBEDKAR TODAY
}

\author{
Dr. Preeti Oza \\ St. Andrew"s College \\ Mumbai University \\ Preetioza1@gmail.com
}

\section{INTRODUCTION}

Subaltern History is a very interesting mirror of the society and after being quiet for such a long time, when it speaks, it shatters many myths, many stereotypes, many positions, many perceptions, many established narratives, and viewpoints. The re-positioning of the Dalit- Buddhist equation and the role of New writings in Dalit Literature has provided a good platform to discuss the entire narrative of Dr. Babasaheb Ambedkar today.

Dalits have been winning their battle against designator and gaining in form of reservation benefits from the days of British rule in India. By 1980s the Dalits included Sudras in their camp and began the united fight against Casteism with Bahujan identity and demanding a proportionate share in various fields. This, in turn, triggered sub-caste identity movements demanding respectable identity and equal share in fields of education employment and politics in India. Today identity politics is a special area of study attracting the attention of students, social scientists and social policy makers in India

Identity politics can be defined as "the political arguments that focus upon the interest and perspectives of groups with which people identify". This includes the ways in which people's politics may be shaped by aspects of their identity with the use of being a part of any social organizations like race, class, religion, gender, ethnicity, ideology, nation, sexual orientation, culture, information preference, history, musical or literary preference, medical conditions, professions or hobbies. Not all members of any given group are necessarily involved in identity politics.

Though the amashudra were grouped under 'indus, they were in reality, followers of Buddha Dhamma, long before Ambedkar proposed conversion. These people probably did not know what was greed and envy. These people were happy with what they had and also were always ready to share. They did not sell their milk or food. If there was Acess, it would be shared with another family who did not have enough food. In such ways, they should belong to the highest castes in the country, by their actions." (Disanayke, 1998)

In plural societies assertion for identity and autonomy on the basis of ethnicity, language, religion, and culture has been a common problem. Owing to the majoritarian form of governance only the majoritarian groups are benefited in the process of modernization and they form the mainstream of the socio-political fabric (Alcoff, 2006). The minority groups remain isolated, deprived and at the periphery of the system. This is the root cause of the phenomenon called the Identity Politics. This paper is an effort to contextualize and historicize academic critical readings on Identity politics in the modern Globalized Asian Context. Though it is not an attempt to fill the void by narrating the modes of articulation of identity politics in South Asia, which is a vast and complex subject but to throw some light on why identity politics emerged as a dominant force in the region in the $21^{\text {st }}$ century.

Dr. Ambedkar is the apostle of the Dalits. Historically, he is the first to break Sanatan Hindu traditions of the ban on learning for the untouchables. His own achievements in the field of learning are the source of pride, prestige, and inspiration to the Dalits. Because, first, Dalits were supposed to be ineligible to learn due to wanting of blessings from Goddess of learning and secondly, no man among the Dalits has risen previously to the height of Dr. Ambedkar at the caste level, as well as at the national level. (Rao, 2009)

\section{DR. AMBEDKAR'S VIEWS ON IDENTITY CONFLICT:}

Dr. Babasaheb Ambedkar viewed that the war between settled (Dalits) Tribes and Nomadic Tribes (Aryans) in a primitive stage of their development was nothing but a war for economic benefits and existence. "The purpose of Aryan war against Dalits according to Dr.

B.R. Ambedkar were (1) stealing the cattle, (2) stealing women and (3) stealthily grazing of cattle in the pastures belonging to other tribes" ( Omvedt, 1996) 


\section{GAP INTERDISCIPLINARITIES -}

In 1931, in the Round Table Conference, Dr. B.R.Ambedkar suggested being renamed as protestant Hindus or Non-conformist. His political objective was an identity for securing special protection for the rights independent of the Hindu majority. There were four In India during 1920-30s (1) British rule desired Christians out of Hindus, (2) various caste / social to have a separate identity such as Adi-Dharmas AdiHindus Mahasaba wanted a common identity. B.R.Ambedkar desired an identity of Protestant separate identity.

Mahatma Gandhi labeled untouchables as Harijans to suit his politics in the 1930's. It was said, as politician and Mahatma, Gandhi sought to weave the divergent interests in India into a unified opposition to British, at that time, trying to pursue a course of reform without rending the social fabric of Indian society". But, Dr. B.R.Ambedkar demanded separate identity and separate representation in the form of communal representation in 1919. In a statement submitted to the Southborough committee, he demanded communal representation to untouchables, believing that there will be no protection for the rights of Dalits in the Hindu majority. Conceding the demand of Babasaheb, the British government declared "Communal Award" in 1932 granting separate electorate to untouchables under which the untouchables can elect their representatives from their electorate. But Gandhi opposed their separate identity and labeled them as Harijan as part of his political strategy. ( Zelliot, 1972)

The untouchables were asserting themselves for from bondage of Hindus but Mr. Gandhi included make them a majority which ultimately advantageous electorate and reserved constituencies by naming Babasaheb says, "it is also an indication of fact selfish and has given the name Harijan to the untouchables Vaishnavism". During the temples entry movement, Ambedkar pledged to state that Hindus will not accept civil context of Dr.B.R. Ambedkar's determination fold Gandhi pledged to retain Dalits in and to swell political status.

DALIT CHRISTIANS: The fact, Dr. B.R. Ambedkar rightly pointed Dalit Christians in India is that Christianity dissolving the feeling of caste from converts, the fact that caste governs the life of Christians of Hindus. There are Brahmin Christians and non-Brahmin Christians. Among NonBrahmin Christians, there are Maratha Christians, Mahar Christians, Mang Christians, and Bhangi Christians. Similarly, in South India, there are Paria Christians, Mala Christians, and Madiga Christians. They would not inter-marry, they would not inter-dine. They are as much casteridden as Hindus are.

\section{NEO-BUDDHISTS AND AMBEDKAR:}

Dr. B. R. Ambedkar desired to own Buddhist identity by conversion into Buddhism and emancipate himself from Hindu Religion and set an example to other Dalits to have the same identity and emancipation. He viewed that, fraternity, equality, and liberty as basic foundations for the development of individual and society. He warned the Dalits that there would be no development so long as they are there in the Hindu religion since these three foundations are absent in the Hindu religion. (Ambedkar, 2011)

A conference of all depressed classes to discuss the issue of conversion was called in October 1935 at Yeola (District Nasik) by Dr. Babasaheb, in which about 10,000 depressed castes representatives attended from various parts of the country. In his speech, Babasaheb expressed his desire to leave the Hindu religion. He said. "It is an unfortunate fact that I have been born a Hindu: It was not in my hands to oppose or change that. But I can say this with utmost gravity and sincerity: I will not die a Hindu" ( Ambedkar, 2014) Twenty years after his declaration to quit Hindu religion Babasaheb took initiation in Buddhism on 14 October 1956. Following Babasaheb thousands of Mahars converted to Buddhism. Thereafter Neo-Buddhist became new identity of Dalits in India.

But Even after four and half decades of Babasaheb conversion, Buddhism could not grow as a popular religion of Dalits in India and benefit them much like Christianity as it failed to provide a God and Godly institutions such as heaven and hell and a hope of another world. Finally, Buddhist conversions of Dalits failed to provide both mundane and otherworldly emancipation to Dalits as it is a Godless religion.

\section{THE OBJECTIVE:}

The term identity politics and movements linked to it came into being during the latter part of the 20th century. Some prominent amongst them are the Class Movements, the Feminist Movements, the Gay, Lesbian and Bisexual Movements, the Disability Movements, the Ethnic Movements, and the Post Colonial Movements. The influence exercised by the identity politics and various movements under the banner of it during the last two centuries in South Asia has been a subject of multidisciplinary inquiries. 
As prof. Ashutosh Varshney puts it: "In the modern world, two different notions of worth have often been at odds: one stemming from the culturally inherited conceptions of groups as better or worse; and another arising out of a decline of social hierarchies and the rise of equality. By challenging the inherited structure or discourse of group hierarchy, the latter inevitably seeks to undermine the former. Identity politics or what we might call the demand for recognition is thus, at its core, essentially the politics of equal dignity and the politics of defiance (or authenticity). It has emerged both in the developing and developed world, and has roots in gender politics, sexual politics, ethnic politics, and religious interpretations, or some combination thereof." ( Varshney, 1993)

\section{DIFFERENT CATEGORIES}

The politics of identity has many hues, demarcated by different states of sensitivity and sensibility prevalent in a society. They can be broadly grouped into two categories:

- The politics of domination and

- The politics of resistance.

The politics of domination is the quest for power for which identity is invoked as a means of mobilization. The politics of resistance is the politics of rights in which identity serves as a cohesive force for achieving internal solidarity. The identity politics of the majority religion belongs to the former, whereas the identity politics of minorities, such as Dalits and Adivasis, to the latter.

\section{POLITICS OF DOMINANCE AND RELIGIOUS FERVOR}

Beginning with the accounts of medieval foreign visitors, a popularly held stereotype about South Asia has been the religious character of the people of the region. In fact, there was nothing particular in the religious life of the people to warrant such a characterization. What led to this impression perhaps was the public performance of rituals and the annual journey undertaken by devotees to a network of pilgrimage centers.

Of the several common characteristics that the modern states in the South Asian region shared, their multicultural and multi-religious compositions have been the most conspicuous. They shaped the demographic pattern, influenced the course of social relations, defined the contours of cultural life and, above all, set certain parameters for the mutual relations of different countries in the region. The relationship between different states was influenced more by recriminations of the past rather than the possibilities of the future, leading to mutual suspicion, distrust and occasional hostility and even armed conflict.

For, „India' is present in the communal discourse of Pakistan and Bangladesh, so are „Pakistan and Bangladesh' in India. The Tamil leaders of India are emotionally involved with the Sinhala-Tamil conflict. Thus the ethnic and religious configurations were major factors in the formation and articulation of identity politics in individual countries. In all of them, however, identity politics has been in conflict with national and secular politics. In India, it goes back to the period of the anti-colonial national movement in which an undercurrent of caste and religious identities was present.

One interesting observation here is the comparison between the state as a "Salad Bowl" and the state as a "melting pot". The secular politics and its demand for recognition in the sphere where religion came to interact with politics, is called the "salad bowl" ideology, which is also coming to be called "secular nationalism." A state governed by such an ideology would maintain "equal distance" from all religions. The greatest challenge to this view has come from Hindu nationalism, a powerful force since 1989. The Hindu nationalist view of the nation is embedded in a "melting pot" model. Hinduism, according to this narrative, gives India its distinctive national identity, and other religions must assimilate to the Hindu center. India, according to this narrative, is originally the land of the Hindus. (Akiner, 1997)

\section{POLITICS OF RESISTANCE AND MARGINALISED GROUPS:}

As Sarah Joseph, in Interrogating Culture: Critical Perspectives on Contemporary Social Theory observes: "The process of selection of identities by the subject is more or less voluntary one, differences of power and privilege in society also play its part in the process. The process of identity formation is also influenced by the differences in the power of inequality between groups". ( Joseph,1998)

The identity politics of marginalized and oppressed groups is rooted in opposition and resistance. Their marginality defines their identity, and the aim of the politics emerging out of it is more often aimed at 
inclusion and equality. This genre of identity politics is fundamentally different from the politics of Hindu religious identity. While the latter aims at the hegemony over marginalized groups, the main character of the former are resistance.

\section{DALIT IDENTITY POLITICS:}

Caste is considered as constituting the basic identity of people in the Indian subcontinent. Classically, it draws upon a hierarchical notion and a corresponding association of rights and obligations. Caste thus formed a continuum ranging from the notional superior-most Brahmin sub-caste to the inferior-most untouchable caste, the precise identity of which would be impossible to determine. This haziness of castes is the result of their sheer numbers as well as their dynamism. Caste, contrary to its commonplace notion, is not a static category and has been constantly evolving through splits and mergers, in turn giving birth to new castes which, according to their material strength, stake claim to a higher ritual position vis-à-vis other castes in their respective locale. Likewise, geography determines the varying modes of living of people, which also made a difference in the social position of different castes. Caste thus constitutes a life world of the people in the subcontinent with fluid boundaries.

At the root of „identity politics" lies the idea that only those experiencing a particular form of oppression can either define or fight against it. The battle against gender discrimination cannot be fought by men, just as the anti-racist struggles can only be waged by the victims of racism. In the context of caste, the issue of identity came into prominence when Dr. Ambedkar publicly denounced the Depressed Classes Mission of V.R. Shinde in a Depressed Classes Conference in May 1920 at Nagpur. This declaration effectively catalyzed self-articulation of the Dalit movement and stressed the importance of an autonomous "Dalit" identity. The „Dalit" identity also acted as a shield against Dalits drifting, either to the capitalist Congress as

„Harijans" or the communists as „proletariat". ( Omvedt, 2006)

Historically this process has been very systematically induced in the Indian Psyche. This process of ethnicization reached its radical high point in the non-Brahmin movement launched by Jyotiba Phule in Maharashtra and later, in the Dravidian movement of Periyar in Tamil Nadu. It was basically catalyzed by the new ideas coming from European missionaries, which were propagated in schools, and eventually culminated in the theory of an „Aryan race". Based on a study of the Indo-European linguistic family, William Jones in 1792 had invoked a notion of common, original race whose branches had migrated towards Europe and India. This notion was further developed during the mid-19th century by German Indologists such as Albert Weber, R. Roth, A. Kuhn, and J. Mohl, constructing theories of a "Sanskritic race" and "Vedic people". When these ideas reached India they were immediately picked up by the likes of Tilak and Dayanand Saraswati for Hindu revivalism, arousing self-esteem among Hindus that they were the superior people who once ruled the world.

But These very ideas were used by Mahatma Jyotiba Phule for an entirely opposite purpose. He constructed the ethnic identity of Bahujan (shudra-atishudra), castigating Brahmins as invaders who enslaved the natives and thus provided the lower castes with the motive force to fight. For the first time, all non-Brahmin castes were invited to unite on the basis of a common ethnic background - as the original inhabitants of India - against Brahmin domination. Although Phule"s Satyashodhak idiom was imbued with the symbols of kshatriyahood, the movement escaped the Sanskritization trap since it rejected the upper castes as role models, calling them invaders, and despised their culture.

The most powerful articulation of identity politics has occurred among the members of the lower castes, who were traditionally excluded from mainstream life in society. The emergence of Dalit consciousness can be traced to the period of the Renaissance, even if the renaissance mainly addressed the problems faced by the upper castes, except in Maharashtra, Tamil Nadu, and Kerala.

Caste mobilization for political purposes followed two inherent strategies: one, to assimilate many castes under the same identity and stake a claim for a larger part of the pie, and two, to cordon themselves off from being usurped by others in this process in order to preserve their own share for themselves. While the former strategy was adopted by the upper castes, the latter came to be adopted by the maturing Dalit movement under Dr.Babasaheb Ambedkar. 
CONCLUSION:

Though being very important and widespread, Identity Politics School of Thought is never been left unquestioned. Many critics have raised many pertinent questions with the reference to Globalization and macro/ micro Identity Politics. Some of them are:

- Have religious and caste identity politics been influenced by the political ideology?

- Has the cross-border movement of capital, labor, goods, services, technology and ideas, and India's greater integration into the international system, left a discernible impact on how India's language and religious groups, castes and tribes have formulated their politics and made claims on, or against, the policy?

- Has inter or intra migration/ conversion played any specific role in solidifying identity politics in India?

\section{REFERENCES:}

You build your house, we'll build ours": The Attractions and Pitfalls of Dalit Identity Politic Social Identities: Journal for the Study of Race, Nation and Culture, Volume 11, Issue 6, 2005

Akiner, Shirin. "Melting pot, salad bowl-cauldron? Manipulation and mobilization of ethnic and religious identities in Central Asia." Ethnic and Racial Studies 20.2 (1997): 362-398.

Alcoff, Linda, ed. Identity Politics Reconsidered. New York: Palgrave MacMillan., 2006

Ambedkar, Bhimrao Ramji. Annihilation of caste: The annotated critical edition. Verso Books, 2014.

Ambedkar, Bhimrao Ramji. The Buddha and his dhamma: A critical edition. Oxford University Press, 2011.

Dhammadaya Dissanayake, Dalit Literature, and Buddha, https://www.academia.edu/19876291/Dalit_Literature_and_Buddha_Dhamma

Joseph, Sarah. "Interrogating Culture Critical Perspectives on Contemporary Social Theory." (1998).

K. Oomen, Nation, Civil Society, and Social Movements: Essays in Political Sociology, New Delhi, Sage, 2004.

Omvedt, Gail. Dalit Visions: The anti-caste movement and the construction of an Indian identity. Orient Blackswan, 2006.

Omvedt, Gail. Dalits and the democratic revolution: Dr. Ambedkar and the Dalit movement in Colonial India. SAGE Publications India, 1994.

Rao, Anupama. The caste question: Dalits and the politics of modern India. Univ of California Press, 2009.

Sarah Joseph, Interrogating Culture: Critical Perspectives on Contemporary Social Theory, New Delhi, Sage, 1998.

Varshney, Ashutosh. "Contested meanings: India's national identity, Hindu nationalism, and the politics of anxiety." Daedalus (1993): 227-261.

Zelliot, Eleanor. "Gandhi and Ambedkar: A study in leadership." The untouchables in contemporary India (1972): 69-95. 